\title{
Autoimmune conditions and hairy cell leukemia: an exploratory case-control study
}

\author{
Lesley A Anderson ${ }^{1 *}$, Eric A Engels ${ }^{2}$
}

\begin{abstract}
Background: Case reports suggest that hairy cell leukemia (HCL) may be associated with autoimmune conditions, however no systematic investigations in this area have been undertaken.

Methods: Using the United States Surveillance, Epidemiology, and End Results Medicare linked database, we conducted an exploratory study comparing autoimmune conditions in $418 \mathrm{HCL}$ cases (aged $\geq 65$ years) and 160,086 controls.

Results: Overall, the proportion with autoimmune conditions was similar between $\mathrm{HCL}$ cases and controls $(\mathrm{n}=79$ (18.9\%) and $n=29,284(18.3 \%)$, respectively). Before diagnosis/selection, there was no overall difference in the prevalence of autoimmune conditions in $\mathrm{HCL}$ cases $(n=37,8.9 \%)$ compared with controls $(n=14,085,8.8 \%), p=$ 0.969. However, compared with controls, $\mathrm{HCL}$ cases more frequently had sarcoidosis (OR 9.6, 95\%Cl 2.4-39.5), Sjögren syndrome (OR 6.1,95\% Cl 2.0-19.3) and erythema nodosum (OR 37, 95\%Cl 4.9-284) before diagnosis. Autoimmune conditions were also more common in $\mathrm{HCL}$ cases than controls around the time of diagnosis/ selection $(p<0.001)$ but not subsequently.

Conclusions: The findings do not support an overall relationship between autoimmune conditions and $\mathrm{HCL}$, although the association with some autoimmune conditions prior to $\mathrm{HCL}$ diagnosis may warrant further investigation. Our findings also suggest that autoimmune conditions in $\mathrm{HCL}$ patients may be detected around the time of diagnosis.
\end{abstract}

\section{Introduction}

Hairy cell leukemia (HCL) is a rare, indolent, B-cell neoplasm, accounting for approximately $2 \%$ of all nonHodgkin lymphomas (NHLs) in the U.S. [1]. Organic solvents and some medical conditions including anemia could be related to development of HCL [2]. Factors affecting the immune system, including autoimmune conditions, are associated with an elevated risk of several other NHL subtypes [3]. Case reports have described the occurrence of autoimmune conditions antecedent to and following diagnosis or treatment of HCL [4-8], suggesting that autoimmune conditions may be associated with this malignancy.

Nonetheless, no prior study has systematically assessed associations between a range of autoimmune conditions

\footnotetext{
* Correspondence: l.anderson@qub.ac.uk

'Cancer Epidemiology and Health Services Research Group, Centre for Public Health, School of Medicine, Dentistry and Biomedical Sciences, Queen's

University Belfast, Northern Ireland, UK

Full list of author information is available at the end of the article
}

and HCL. We therefore conducted an exploratory study using linked U.S. data from the Surveillance, Epidemiology, and End Results (SEER) cancer registry program and Medicare to investigate the relation between a range of autoimmune conditions and $\mathrm{HCL}$, separately examining the periods before, at, and after $\mathrm{HCL}$ diagnosis.

\section{Methods}

The SEER-Medicare Assessment of Hematopoietic Malignancy Risk Traits (SMAHRT) Study is a population-based study of hematopoietic malignancies in elderly adults, using SEER-Medicare linked data [9]. The SEER program (1973-2002) includes data on cancer cases covering approximately $25 \%$ of the U.S. population for the most recent years. Medicare provides federally funded health insurance for approximately $97 \%$ of persons aged $\geq 65$ years in the U.S. All Medicare beneficiaries have Part A coverage for hospital inpatient care, and approximately 96\% subscribe to Part B coverage for physician and

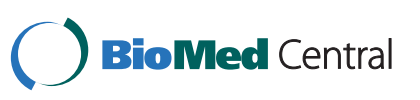


outpatient services. The SEER-Medicare database linkage includes Medicare enrollment and claims data (19862002) for SEER cancer cases diagnosed through December 2002, and for a 5\% random sample of Medicare beneficiaries residing in SEER registry areas [10].

The SMAHRT Study includes as cases individuals from the SEER-Medicare database with a hematopoietic malignancy. Cases were aged 67-99 years at diagnosis, with at least 12 months of prior Part A and Part B coverage and without enrollment in a health maintenance organization to ensure adequate accrual of information on medical conditions prior to malignancy diagnosis. For the present analyses, we included cases with HCL (International Classification of Diseases for Oncology Version 3, code 9940) diagnosed between 1987 and 2002.

The SMAHRT Study includes two controls per hematopoietic malignancy case $(n=83,113)$, selected from the $5 \%$ random sample of Medicare beneficiaries. Controls were frequency matched to all hematopoietic malignancy cases by calendar year of diagnosis, age in five categories (67-69, 70-74, 75-79, 80-84, 85-99 years) and gender. Cases and controls with a prior diagnosis of human immunodeficiency virus infection were excluded. All SMAHRT Study controls were utilized in the present analysis $(\mathrm{n}=160,086)$.

Using Medicare data, we searched for claims for specific autoimmune conditions. Subjects were classified as having an autoimmune condition if they had $\geq 1$ hospital claim, or $\geq 2$ physician or outpatient claims for the condition at least 30 days apart. Autoimmune conditions with a prevalence of $\geq 0.1 \%$ in control subjects were included in the study. Autoimmune conditions were categorized as being before, at, or after "diagnosis/selection" according to whether the above definition was first met in the period $>12$ months before, from 12 months before until 12 months after, or $>12$ months after HCL diagnosis (in cases) or selection (in controls).

Chi-square tests were used to compare the overall proportion of cases and controls with autoimmune conditions. Logistic regression was used to calculate ORs comparing the prevalence of autoimmune conditions before diagnosis/selection in cases and controls. Analyses were adjusted for the matching factors and race (white, non-white). Additional analyses were restricted to whites only or to females only. Proportional hazards regression, adjusting for matching factors, was used to compare the time to diagnosis of autoimmune conditions after HCL diagnosis/control selection with patients censored at the date of death or end of study date (December 31, 2002), whichever occurred earlier.

\section{Results}

The study included 418 HCL cases (Table 1). Compared with controls $(n=160,086)$, HCL cases were more likely to be male, younger, and white. Duration of Medicare coverage and the number of prior physician and outpatient claims were similar for cases and controls. Controls tended to have more hospital claims than HCL cases.

Overall, 79 (18.9\%) HCL cases and 29,284 (18.3\%) controls had at least one of the autoimmune conditions presented in Table 2, $\mathrm{p}=0.749$. During the period before diagnosis/selection, there was no overall difference in the prevalence of autoimmune conditions in HCL cases $(\mathrm{n}=37,8.9 \%)$ compared with controls $(\mathrm{n}=$ $14,085,8.8 \%), p=0.969$. Nonetheless, among specific autoimmune conditions, sarcoidosis (OR 9.6, $\mathrm{p}=0.002$ ), Sjögren syndrome (OR 6.1, $\mathrm{p}=0.002)$, and erythema nodosum (OR 37, p < 0.001) were more common in cases than controls, despite small numbers (Table 2). Most cases were diagnosed with the respective autoimmune condition in the 1-5 year period before diagnosis. When we restricted our analyses to whites only or females only the point estimates were similar (data not shown).

In the period after diagnosis/selection, no autoimmune conditions occurred more frequently in HCL cases compared to controls, Table 2. Overall, 23 (5.5\%) HCL cases and 11,993 (7.5\%) controls had at least one autoimmune condition in this period, $\mathrm{p}=0.122$.

Autoimmune conditions were more common in HCL patients $(n=26,6.2 \%)$ at the time of diagnosis than controls $(\mathrm{n}=5,146,3.2 \%), \mathrm{p}<0.001$. Of the autoimmune conditions, ankylosing spondylitis, Crohn disease, Hashimoto thyroditis, systemic lupus erythematosus, pernicious anemia, and Sjögren syndrome were more commonly reported in cases than controls during this time period, Table 2.

\section{Discussion}

This exploratory case-control study of $418 \mathrm{HCL}$ cases is the first to examine associations with a diverse range of autoimmune conditions. The rarity of this NHL subtype presents a challenge for systematic epidemiologic study, and prior reports have mostly consisted of small case series or case reports. Although our study included more HCL cases than previous studies, most autoimmune conditions are also uncommon. Thus, the associations reported were based on few cases, which led to imprecise estimates.

Although we found no overall difference in the proportion of cases and controls with an autoimmune condition, there was some evidence for an excess of sarcoidosis, erythema nodosum and Sjögren syndrome occurring antecedent to HCL diagnosis. Overlap between these three conditions has previously been reported [11] and erythema nodosum $[8,12]$ and sarcoidosis [8] have been reported in HCL patients. Sjögren syndrome and several other autoimmune conditions are 
Table 1 Characteristics of hairy cell leukemia cases and controls.

\begin{tabular}{|c|c|c|c|}
\hline & $\begin{array}{l}\text { Hairy cell leukemia } \\
\text { cases } \\
(n=418)\end{array}$ & $\begin{array}{l}\text { Controls } \\
(n=160,086)\end{array}$ & $\begin{array}{l}P \text { - } \\
\text { value }\end{array}$ \\
\hline Gender & & & $\begin{array}{l}< \\
0.001\end{array}$ \\
\hline Male & $285(68.2 \%)$ & 78,620 (49.1\%) & \\
\hline Female & $133(31.8 \%)$ & 81,466 (50.9\%) & \\
\hline Age, years & & & 0.003 \\
\hline $67-69$ & $70(16.8 \%)$ & 19,135 (12.0\%) & \\
\hline $70-74$ & $122(29.2 \%)$ & 40,611 (25.4\%) & \\
\hline $75-79$ & $96(23.0 \%)$ & $41,724(26.1 \%)$ & \\
\hline $80-84$ & $76(18.2 \%)$ & 32,091 (20.1\%) & \\
\hline $85-99$ & 54 (12.9\%) & $26,902(16.6 \%)$ & \\
\hline Selection year & & & 0.401 \\
\hline 1987-1996 & $203(48.6 \%)$ & $71,396(44.6 \%)$ & \\
\hline 1997-1999 & $69(16.5 \%)$ & $26,946(16.8 \%)$ & \\
\hline $2000-2001$ & 97 (23.2\%) & $40,750(25.5 \%)$ & \\
\hline 2002 & $49(11.7 \%)$ & 20,994 (13.1\%) & \\
\hline Race/ethnicity & & & $\begin{array}{l}< \\
0.001\end{array}$ \\
\hline White & 390 (93.3\%) & $\begin{array}{l}135,280 \\
(84.5 \%)\end{array}$ & \\
\hline Black & $10(2.4 \%)$ & 10,897 (6.8\%) & \\
\hline Asian & $5(1.2 \%)$ & $5,629(3.5 \%)$ & \\
\hline Hispanic & $<5$ & $3,408(2.1 \%)$ & \\
\hline $\begin{array}{l}\text { Native American } \\
\text { Indian }\end{array}$ & $<5$ & $448(0.2 \%)$ & \\
\hline Other/unknown & $8(1.9 \%)$ & $4,424(2.8 \%)$ & \\
\hline $\begin{array}{l}\text { Duration of Medicare } \\
\text { benefits }\end{array}$ & 177 (42.3\%) & 62,264 (38.9\%) & 0.359 \\
\hline 12-57 months & 99 (23.7\%) & 36,842 (23.0\%) & \\
\hline 58-93 months & $71(17.0 \%)$ & 30,696 (19.2\%) & \\
\hline 94-136 months & $71(17.0 \%)$ & 30,284 (18.9\%) & \\
\hline$\geq 137$ months & & & \\
\hline $\begin{array}{l}\text { Number of physician } \\
\text { claims* }\end{array}$ & & & 0.590 \\
\hline $0-20$ & $183(43.8 \%)$ & $68,324(42.7 \%)$ & \\
\hline $21-57$ & 80 (19.1\%) & 30,532 (19.1\%) & \\
\hline $58-127$ & $86(20.6 \%)$ & 30,763 (19.2\%) & \\
\hline$\geq 128$ & $69(16.5 \%)$ & 30,467 (19.0\%) & \\
\hline $\begin{array}{l}\text { Number of outpatient } \\
\text { claims* }\end{array}$ & & & 0.808 \\
\hline 0 & 166 (39.7\%) & $62,453(39.0 \%)$ & \\
\hline $1-3$ & 81 (19.4\%) & 32,154 (20.1\%) & \\
\hline $4-7$ & $61(14.6 \%)$ & $21,293(13.3 \%)$ & \\
\hline $8-15$ & $56(13.4 \%)$ & 20,722 (12.9\%) & \\
\hline$\geq 16$ & $54(12.9 \%)$ & $23,464(14.7 \%)$ & \\
\hline $\begin{array}{l}\text { Number of hospital } \\
\text { claims* }\end{array}$ & & & 0.035 \\
\hline 0 & 235 (56.2\%) & 87,059 (54.4\%) & \\
\hline 1 & 90 (21.5\%) & 28,505 (17.8\%) & \\
\hline
\end{tabular}

Table 1: Characteristics of hairy cell leukemia cases and controls. (Continued)

\begin{tabular}{l}
\begin{tabular}{lll}
\hline $2-3$ & $49(11.7 \%)$ & 25,255 \\
$\geq 4$ & $44(10.5 \%)$ & $19,267(12.0 \%)$
\end{tabular} \\
\hline Notes: \\
All entries are number of subjects (\%). When the number of subjects was less \\
than 5, the entry indicates "< 5 " rather than specifying the number, in \\
accordance with the SEER-Medicare data use agreement. \\
*The number of claims excludes the one year period prior to diagnosis/ \\
selection.
\end{tabular}

associated with an increased risk of developing other NHL subtypes [3], which might be explained by antigen-driven chronic inflammation [13]. In addition, nonsteroidal anti-inflammatory drugs have been associated with a three-fold increased risk of HCL [2]. While use of immunosuppressive medications to treat some autoimmune conditions has been linked to lymphoma, a recent study has suggested that the severity of the condition, not its treatment, is responsible for the added risk [14]. If certain autoimmune conditions do increase the risk of HCL, it may therefore be due to the autoimmune disease itself rather than its treatment. Most cases with these autoimmune conditions were diagnosed in the 1-5 year period prior to diagnosis suggesting the possibility that some of these conditions may be part of the early disease process of HCL. However, there were too few cases for us to reliably evaluate the time from first claim for the autoimmune condition until $\mathrm{HCL}$ diagnosis, which would have shed additional light.

In contrast to these restricted associations, we found a much broader range of associations between HCL and various autoimmune conditions at the time of diagnosis. This observation could have several explanations: causality in either direction (i.e., the autoimmune condition or its treatment leading to $\mathrm{HCL}$, or HCL or its treatment leading to the autoimmune condition), the presence of a common underlying risk factor for both the autoimmune condition and HCL, or over diagnosis in HCL patients undergoing medical evaluation for HCLrelated symptoms which would result in detection bias. Arguing against this last possibility, however, we note that the prevalence of non-immune-related medical conditions (including hypertension, hyperlipidemia, peptic ulcer disease, migraine, depression, and gastroesophageal reflux) were not significantly higher in HCL patients compared to controls at the time of diagnosis/selection (data not shown).

Limitations and strengths of our study should be considered. We relied upon Medicare claims to determine the presence of autoimmune conditions. To reduce the 
Table 2 Risk of autoimmune conditions in hairy cell leukemia cases compared to controls

\begin{tabular}{|c|c|c|c|c|c|}
\hline $\begin{array}{l}\text { Autoimmune } \\
\text { condition }\end{array}$ & $\begin{array}{r}\text { Controls with } \\
\text { autoimmune } \\
\text { condition }\end{array}$ & $\begin{array}{r}\text { HCL cases with } \\
\text { autoimmune } \\
\text { condition }\end{array}$ & $\begin{array}{l}\text { Association before } \mathrm{HCL} \\
\mathrm{dx} / \text { control selection }\end{array}$ & $\begin{array}{l}\text { Association at } \mathrm{HCL} \\
\mathrm{dx} / \text { control selection }\end{array}$ & $\begin{array}{l}\text { Association after } \mathrm{HCL} \\
\mathrm{dx} / \text { control selection }\end{array}$ \\
\hline & No. (\%) & No. (\%) & Odds Ratio $(95 \% \mathrm{Cl})^{*}$ & Odds Ratio $(95 \% \mathrm{Cl})^{*}$ & Hazard Ratio $(95 \% \mathrm{Cl})^{*}$ \\
\hline Addison disease & $614(0.4)$ & $<5$ & $2.1(0.3-15.2)$ & - & $1.1(0.9-1.3)$ \\
\hline Alopecia areata & $169(0.1)$ & 0 & - & - & - \\
\hline $\begin{array}{l}\text { Ankylosing } \\
\text { spondylitis }\end{array}$ & $251(0.2)$ & $<5$ & - & $12.2(1.7-90.7)$ & - \\
\hline $\begin{array}{l}\text { Chronic } \\
\text { rheumatic heart } \\
\text { disease }\end{array}$ & $10,405(6.5)$ & $23(5.5)$ & $0.8(0.4-1.7)$ & $1.4(0.6-3.2)$ & $1.0(1.0-1.1)$ \\
\hline Crohn disease & $546(0.3)$ & $<5$ & - & $10.2(2.5-41.7)$ & - \\
\hline $\begin{array}{l}\text { Discoid lupus } \\
\text { erythematosus }\end{array}$ & $273(0.2)$ & 0 & - & - & - \\
\hline $\begin{array}{l}\text { Erythema } \\
\text { nodosum }\end{array}$ & $86(0.1)$ & $<5$ & $37(4.9-284)$ & - & - \\
\hline Giant cell arteritis & $899(0.6)$ & $<5$ & $2.2(0.6-9.1)$ & - & - \\
\hline $\begin{array}{l}\text { Goodpasture } \\
\text { syndrome }\end{array}$ & $13(0.0)$ & 0 & - & - & - \\
\hline Graves disease & $727(0.5)$ & 0 & - & - & - \\
\hline $\begin{array}{l}\text { Hashimoto } \\
\text { thyroditis }\end{array}$ & $588(0.4)$ & $<5$ & $1.7(0.2-12.1)$ & $10.3(2.5-42.3)$ & - \\
\hline $\begin{array}{l}\text { Systemic lupus } \\
\text { erythermatosus }\end{array}$ & $545(0.3)$ & $<5$ & $1.8(0.3-13.0)$ & $7.2(2.3-22.8)$ & $1.1(0.9-1.4)$ \\
\hline $\begin{array}{l}\text { Meniere } \\
\text { syndrome }\end{array}$ & $800(0.5)$ & $<5$ & $1.0(0.1-7.2)$ & - & $1.1(0.9-1.4)$ \\
\hline Myasthenia gravis & $232(0.1)$ & 0 & - & - & - \\
\hline Pernicious anemia & $5,229(3.3)$ & $17(4.1)$ & $1.1(0.5-2.8)$ & $3.4(1.6-7.1)$ & $1.0(0.9-1.1)$ \\
\hline Polymyositis & $206(0.1)$ & 0 & - & - & - \\
\hline $\begin{array}{l}\text { Polymyalgia } \\
\text { rheumatica }\end{array}$ & $2,721(1.7)$ & $9(2.6)$ & $1.5(0.5-3.9)$ & $1.1(0.2-8.0)$ & $1.1(1.0-1.2)$ \\
\hline Psoriasis & $2,655(1.7)$ & $<5$ & $0.8(0.2-2.3)$ & $1.0(0.1-7.0)$ & - \\
\hline $\begin{array}{l}\text { Rheumatoid } \\
\text { arthritis }\end{array}$ & $6,557(4.2)$ & $12(4.1)$ & $1.3(0.7-2.5)$ & $1.0(0.2-3.9)$ & $0.9(0.7-1.1)$ \\
\hline Sarcoidosis & $167(0.1)$ & $<5$ & $\underline{9.6(2.4-39.5)}$ & & - \\
\hline $\begin{array}{l}\text { Localised } \\
\text { scleroderma }\end{array}$ & $345(0.2)$ & 0 & - & - & - \\
\hline Systemic sclerosis & $156(0.1)$ & 0 & - & - & - \\
\hline Sjögren syndrome & $472(0.3)$ & $5(1.2)$ & $\underline{6.1(2.0-19.3)}$ & $7.9(1.1-57.5)$ & $1.2(0.9-1.5)$ \\
\hline Ulcerative colitis & $951(0.6)$ & $<5$ & $0.8(0.1-5.6)$ & $2.8(0.4-19.8)$ & - \\
\hline
\end{tabular}

Notes:

Abbreviations: $\mathrm{HCL}$ hairy cell leukemia, $\mathrm{dx}$ diagnosis.

The table includes only autoimmune conditions that had a prevalence of greater than $0.1 \%$ in controls. Associations that were significant at $p<0.05$ are underlined. Observations where the number of exposed cases or controls is between 1 and 4 are listed as " $<5^{\prime \prime}$ to preserve subjects' anonymity, in accordance with the SEER-Medicare data use agreement.

Associations that are significant at $\mathrm{p}<0.05$ are underlined.

*Analyses were adjusted for age (67-69, 70-74, 75-79, 80-84 and 85-99 years), gender, race (white, non-white) and selection year (1987-1996, 1997-1999, 20002001, 2002).

possibility of misdiagnosis, we only considered subjects as having an autoimmune condition if they had a hospital diagnosis, or at least two physician or outpatient claims at least 30 days apart. In addition, our study was limited to HCL cases aged $>65$ years, which comprise only $37.8 \%$ of U.S. cases [15]. Our results may not be generalizable to younger HCL cases. Furthermore, as noted above, the associations with sarcoidosis, Sjögren syndrome, and erythema nodosum although strong (ORs 9.6, 6.1 and 37, respectively) were based on few affected HCL cases and may have occurred by chance. Given the rarity of HCL, our study is the largest to date. Our study has several additional strengths, including population-based sampling of HCL cases, a large number of controls representative of the Medicare population, and availability of Medicare claims files, enabling 
the systematic evaluation of numerous autoimmune conditions.

\section{Conclusions}

In conclusion, our study found little difference in the occurrence of autoimmune conditions between $\mathrm{HCL}$ cases and controls except at the time around HCL diagnosis. Despite small numbers of affected individuals, sarcoidosis, Sjögren syndrome and erythema nodosum were associated with an increased risk of subsequent HCL. Chance, chronic immune stimulation or medication used in the treatment of these autoimmune conditions may explain the findings. Further investigation of these exploratory findings may be warranted.

\section{Acknowledgements}

This study used the linked SEER-Medicare database. The interpretation and reporting of these data are the sole responsibility of the authors. The authors acknowledge the efforts of the Applied Research Program, $\mathrm{NCl}$; the Office of Research, Development and Information, CMS; Information Management Services (IMS), Inc.; and the Surveillance, Epidemiology, and End Results (SEER) Program tumor registries in the creation of the SEERMedicare database. The authors thank Winnie Ricker and Ruth Parsons, Information Management Services, Rockville, MD for constructing the dataset, and our colleagues on the SMAHRT Study, who provided advice and assistance with the SEER-Medicare dataset. This research was supported by the Intramural Research Program of the National Cancer Institute. The Research and Development Office, Northern Ireland, funded Dr. Lesley Anderson to participate in the Cancer Prevention Fellowship Program, Office of Preventive Oncology, National Cancer Institute. The authors reported no potential conflicts of interest.

\section{Author details}

${ }^{1}$ Cancer Epidemiology and Health Services Research Group, Centre for Public Health, School of Medicine, Dentistry and Biomedical Sciences, Queen's University Belfast, Northern Ireland, UK. ${ }^{2}$ Infection and Immunoepidemiology Branch, Division of Cancer Epidemiology and Genetics, National Cancer Institute, Rockville, MD, USA

\section{Authors' contributions}

EAE and LAA conceived the study idea, LAA conducted the statistical analyses, EAE and LAA wrote the manuscript. All authors read and approved the final manuscript.

\section{Competing interests}

The authors declare that they have no competing interests.

Received: 6 July 2010 Accepted: 4 October 2010

Published: 4 October 2010

\section{References}

1. Morton LM, Wang SS, Devesa SS, Hartge P, Weisenburger DD, Linet MS Lymphoma incidence patterns by WHO subtype in the United States, 1992-2001. Blood 2006, 107:265-276.

2. Oleske D, Golomb HM, Farber MD, Levy PS: A case-control inquiry into the etiology of hairy cell leukemia. Am J Epidemiol 1985, 121:675-683.

3. Ekstrom SK, Vajdic CM, Falster M, Engels EA, Martinez-Maza O, Turner J, Hjalgrim $H$, Vineis $P$, Seniori Costantini A, Bracci PM, Holly EA, Willett E, Spinelli JJ, La Vecchia C, Zheng T, Becker N, De Sanjosé S, Chiu BC, Dal Maso L, Cocco P, Maynadié M, Foretova L, Staines A, Brennan P, Davis S, Severson R, Cerhan JR, Breen EC, Birmann B, Grulich AE, Cozen W: Autoimmune disorders and risk of non-Hodgkin lymphoma subtypes: a pooled analysis within the InterLymph Consortium. Blood 2008, 111:4029-4038.
4. Fozza C, Dore F, Bonfigli S, Podda L, Longinotti M: Two cases of chronic lymphoproliferative disorders in psoriatic patients treated with cyclosporine: hairy cell leukemia and Waldenstrom macroglobulinemia. Eur J Dermatol 2005, 15:271-273.

5. Goedert JJ, Neefe JR, Smith FS, Stahl NI, Jaffe ES, Fauci AS: Polyarteritis nodosa, hairy cell leukemia and splenosis. Am J Med 1981, 71:323-326.

6. Krause JR: Aplastic anemia terminating in hairy cell leukemia. A report of two cases. Cancer 1984, 53:1533-1537.

7. Manna R, Perri F, Ghirlanda G, Zeppilli P, Carughi S, Annese V, Uccioli L, Mango G: Association of ankylosing spondylitis with hairy cell leukemia: a previously once reported case. Z Rheumatol 1985, 44:93-96.

8. Schiller G, Said J, Pal S: Hairy cell leukemia and sarcoidosis: a case report and review of the literature. Leukemia 2003, 17:2057-2059.

9. Anderson LA, Pfeiffer R, Warren $J \mathrm{~L}$, Landgren O, Gadalla S, Berndt SI, Ricker W, Parsons R, Wheeler W, Engels EA: Hematopoietic malignancies associated with viral and alcoholic hepatitis. Cancer Epidemiol Biomarkers Prev 2008, 17:3069-3075.

10. Warren JL, Klabunde CN, Schrag D, Bach PB, Riley GF: Overview of the SEER-Medicare data: content, research applications, and generalizability to the United States elderly population. Med Care 2002, 40:IV-18.

11. Ramos-Casals M, Brito-Zeron P, Font J: The Overlap of Sjögren's syndrome with other systemic autoimmune diseases. Sem Arthritis Rheumatism 2007, 36(4):246-255.

12. Patel RR, Kirland EB, Nquyen DH, Cooper BW, Baron ED, Gilliam AC: Erythema nodosum in association with newly diagnosed hairy cell leukemia and group C streptococcus infection. Am J Dermatopathol 2008, 30(2):160-2.

13. Hjelmstrom P. Lymphoid: neogenesis: de novo formation of lymphoid tissue in chronic inflammation through expression of homing chemokines. J Leukoc Biol 2001, 69:331-339.

14. Baecklund E, lliadou A, Askling J, Ekbom A, Backlin C, Granath F, Catrina Al, Rosenquist R, Feltelius N, Sundström C, Klareskog L: Association of chronic inflammation, not its treatment, with increased lymphoma risk in rheumatoid arthritis. Arthritis Rheum 2006, 54(3):692-701.

15. Dores GM, Matsuno RK, Weisenburger DD, Rosenberg PS, Anderson WF: Hairy cell leukemia: a heterogeneous disease? Br J Haematol 2008 142(1):45-51.

doi:10.1186/1756-8722-3-35

Cite this article as: Anderson and Engels: Autoimmune conditions and hairy cell leukemia: an exploratory case-control study. Journal of Hematology \& Oncology 2010 3:35.

\section{Submit your next manuscript to BioMed Central and take full advantage of:}

- Convenient online submission

- Thorough peer review

- No space constraints or color figure charges

- Immediate publication on acceptance

- Inclusion in PubMed, CAS, Scopus and Google Scholar

- Research which is freely available for redistribution

Submit your manuscript at www.biomedcentral.com/submit
C Biomed Central 